« Mardom-šenāsī-ye qālīče-hā-ye gol-barjeste-ye darre-ye Jozān-e Malāyer ». Nāme-ye ensā̄n-šenāsī, $n^{\circ} 5,1383 / 2004$, pp. 65-98. [Ethnologie des tapis à motifs en relief de la vallée de Jozān à Malāyer]

\title{
Hosseyn Mirzaï
}

\section{(2) OpenEdition}

\section{Journals}

Édition électronique

URL : http://journals.openedition.org/abstractairanica/10882

DOI : 10.4000/abstractairanica.10882

ISSN : 1961-960X

Éditeur :

CNRS (UMR 7528 Mondes iraniens et indiens), Éditions de l'IFRI

Édition imprimée

Date de publication : 15 mai 2007

ISSN : 0240-8910

\section{Référence électronique}

Hosseyn Mirzaï, « « Mardom-šenāsī-ye qāličce-hā-ye gol-barjeste-ye darre-ye Jozān-e Malāyer ». Nāmeye ensān-šenāsĭ, n 5, 1383/2004, pp. 65-98. [Ethnologie des tapis à motifs en relief de la vallée de Jozān à Malāyer] », Abstracta Iranica [En ligne], Volume 28 | 2007, document 499, mis en ligne le 18 septembre 2007, consulté le 25 septembre 2020. URL : http://journals.openedition.org/ abstractairanica/10882 ; DOI : https://doi.org/10.4000/abstractairanica.10882

Ce document a été généré automatiquement le 25 septembre 2020.

Tous droits réservés 
« Mardom-šenāsī-ye qālī̌̌e-hā-ye gol-barjeste-ye darre-ye Jozān-e Malāyer ». Nāme-ye ensān-šenāsī, $\mathrm{n}^{\circ}$ 5, 1383/2004, pp. 65-98. [Ethnologie des tapis à motifs en relief de la vallée de Jozān à Malāyer]

\author{
Hosseyn Mirzaï
}

1 Voici un autre travail anthropologique de terrain sur le tapis persan, d'un genre de tissage aussi rarement mentionné. En fait, il date de l'époque seldjoukide et s'exerce jusqu'à nos jours encore à Qom, Kāšān, Eșfahān, Tabrīz et enfin Malāyer, endroit où l'étude a été effectuée.

2 La spécificité de cette catégorie de tapis réside - outre le tissage, les couleurs vives, les tailles diverses, les riches dessins - en un travail de relief qui fait ressortir les motifs floraux de façon étonnamment vivante, d'où l'appellation "gol-e barjeste » (fleur en relief).

3 Après avoir retracé l'historique et décrit les diverses catégories de cette qualité originale de tapis, dans une étude livresque, l'A. se rend sur le terrain à Malāyer et dans les villages environnants et notamment dans la vallée de Jozān où se confondent arbres et fleurs naturels, et ceux matérialisés sur les tapis.

4 L'article est aussi joliment composé que le sujet traité. 
INDEX

Thèmes : 16.1. Iran

\section{AUTEURS}

HOSSEYN MIRZAÏ

Université de Téhéran 